\title{
PENERAPAN PEMBELAJARAN KOOPERATIF TIPE NUMBERED HEAD TOGETHER UNTUK MENINGKATKAN HASIL BELAJAR SISWA PADA MATA PELAJARAN MATEMATIKA DI KELAS IV SDN 21 PAREPARE
}

\author{
St. Maryam. M \\ UPP PGSD Parepare Fakultas Ilmu Pendidikan UNM \\ stmaryamunm@yahoo.co.id
}

\begin{abstract}
ABSTRAK
Permasalahan penelitian ini yaitu apakah penerapan pembelajaran kooperatif tipe Numbered Head Together dapat meningkatkan hasil belajar matematika pada siswa kelas IV SD N 21 Parepare Tujuan penelitian ini yaitu untuk mengetahui penerapan pembelajaran kooperatif tipe Numbered Head Together dalam meningkatkan hasil belajar siswa kelas IV SD N 21 Parepare Pendekatan yang digunakan dalam penelitian ini adalah pendekatan deskriptif kualitatif. Jenis Penelitian yang dilakukan adalah penelitian tindakan kelas yang berdaur ulang/siklus. Tindakan dalam penelitian ini dilakukan dua siklus yang mana setiap siklus melalui empat tahap yaitu perencanaan, pelaksanaan, observasi, dan refleksi. Data diperoleh melalui tes, observasi, dan dokumentasi. Teknik analisis yang digunakan dalam penelitian ini adalah analisis deskriptif kualitatif. Berdasarkan hasil penelitian diperoleh data pada siklus I berada pada kategori kurang, siklus II pada kategori cukup dan siklus III pada kategori sangat baik. Dengan demikian dapat disimpulkan bahwa penerapan pembelajaran kooperatif tipe Numbered Head Together dapat meningkatkan proses dan hasil belajar siswa tentang sifat operasi hitung bilangan bulat pada kelas IV SD N 21 Parepare
\end{abstract}

Kata Kunci: Model Numbered Head Together, hasil belajar.

\section{PENDAHULUAN}

Pendidikan merupakan usaha manusia untuk menyiapkan diri dalam peranannya di masa yang akan datang. Pendidikan dilakukan tanpa ada batasan usia, ruang dan waktu yang tidak dimulai atau diakhiri di sekolah, tetapi diawali dalam keluarga dilanjutkan dalam lingkungan sekolah dan diperkaya oleh lingkungan masyarakat, yang hasilnya digunakan untuk membangun kehidupan pribadi agama, masyarakat, keluarga dan negara. Suatu kenyataan bahwa pemerintah dalam hal ini diwakili lembaga yang bertanggung jawab didalam pelaksanaan pendidikan di Indonesia, akan tetapi pendidikan menjadi tanggung jawab keluarga, sekolah dan masyarakat yang sering disebut dengan Tri Pusat Pendidikan.
Berdasarkan Kurikulum Tingkat Satuan Pendidikan (KTSP) terdapat bidang studi matematika. Pembelajaran matematika di sekolah dasar diharapkan menanamkan pengetahuan anak yang berhubungan dengan ilmu hitung yang akan dimanfaatkan dan diaplikasikan dalam kehidupan sehari-hari. Berdasarkan hal yang telah dikemukakan maka diharapkan guru dituntun untuk menguasai materi bahan ajar dari konsep-konsep matematika yang ada. Salah satu yang termasuk adalah aspek bilangan bulat dan operasi hitungnya. Guru harus mampu mengembangkan pembelajaran matematika dengan pola dan metode mengajar yang tepat agar siswa mampu memahami konsep yang ada serta dapat menarik perhatian siswa untuk lebih berpartisipasi aktif dalam kegiatan 
pembelajaran. Tercapainya tujuan pembelajaran yang dilaksanakan dapat dilihat salah satunya pada hasil belajar siswa itu sendiri melalui nilai yang diperoleh terhadap materi yang telah diajarkan. Salah satu keprihatinan yang diungkapkan dari beberapa pemerhati pendidikan adalah mengenai rendahnya mutu pendidikan yang dihasilkan oleh lembaga-lembaga pendidikan formal. Berdasarkan hasil pengamatan awal yang dilakukan peneliti pada tanggal 08 Oktober 2013 yakni adanya ketidaksesuaian antara apa yang diharapkan dengan kenyataan yang terjadi bahwa upaya untuk meningkatkan hasil belajar siswa khususnya mata pelajaran matematika di SD belum optimal sebagaimana yang diharapkan. Adapun data yang diperoleh peneliti menunjukkan bahwa hasil belajar siswa masih rendah. Hal ini dapat dilihat melalui nilai rata-rata dari 20 siswa kelas IV pada mata pelajaran matematika adalah 60,25 dengan nilai kriteria ketuntasan minimal yang telah ditetapkan adalah 70 untuk mata pelajaran matematika.

20 jumlah siswa yang menjadi subjek penelitian terlihat siswa yang mendapatkan nilai 85-100 dengan kategori sangat baik sebanyak 0 siswa atau $0 \%$, siswa yang mendapatkan nilai 70-84 dengan kategori baik sebanyak 1 siswa atau 5\%, siswa yang mendapatkan nilai 55-69 dengan kategori cukup sebanyak 17 siswa atau $85 \%$, siswa yang mendapatkan nilai 46-54 dengan kategori kurang sebanyak 2 siswa atau $10 \%$ dan siswa yang mendapatkan nilai 0-45 dengan kategori sangat kurang sebanyak 0 siswa atau $0 \%$. Berdasarkan data yang diperoleh dapat dilihat bahwa 19 dari 20 siswa mencapai nilai $<70$, hanya ada 1 siswa yang memenuhi kriteria ketuntasan minimal yang ditetapkan yaitu 70 . Hal ini tentu sangat bertolak belakang dengan pencapaian tujuan pembelajaran yang ingin dicapai. Melihat situasi ini, maka sangat perlu diadakan tindak lanjut yang serius agar hal ini tidak berlanjut. Setelah mengobservasi lebih lanjut, ditemukan beberapa hal yang menjadi faktor penyebab dari rendahnya hasil belajar siswa di SDN 21 Parepare. Faktor menurunnya hasil belajar siswa ternyata berasal dari guru dan siswa itu sendiri.

Adapun faktor yang berasal dari guru yaitu penggunaan strategi pembelajaran yang dilakukan oleh guru masih kurang efektif dalam melibatkan siswa berperan secara aktif dalam proses pembelajaran. Selain itu kurang meratanya pemberian perhatian guru kepada siswa saat proses pembelajaran berlangsung juga menyebabkan partisipasi siswa berkurang. Sedangkan penyebab yang berasal dari siswa yaitu rendahnya minat belajar siswa pada mata pelajaran matematika. Sebagian besar siswa menganggap bahwa pelajaran matematika sangat susah untuk dipelajari sehingga menyebabkan kurangnya semangat dan minat siswa untuk belajar matematika.

Dampak dari hal ini tentu akan berlanjut pada proses pembelajaran di dalam kelas yakni kurangnya keaktifan siswa dalam berpartisipasi pada proses pembelajaran di dalam kelas. Selain itu dengan pelaksanaan proses belajar mengajar yang menggunakan strategi yang kurang efektif sehingga membuat siswa menjadi pasif dalam proses belajar mengajar. Siswa juga cenderung belajar secara individu dan kurangnya berinteraksi dengan teman sekelasnya dalam belajar. Berdasarkan dari hal ini, perlu dicermati secara mendalam bagaimana solusi yang tepat untuk memecahkan masalah ini. Hal ini memerlukan kerjasama antara peneliti dan guru serta tenaga pendidikan yang lainnya. Seharusnya dalam hal ini, guru mampu merancang strategi pembelajaran yang memperhatikan tujuan pembelajaran matematika dan dapat meningkatkan kualitas pembelajaran di dalam kelas yang berdampak pada peningkatan hasil belajar siswa. Dalam hal ini guru dituntut untuk dapat menguasai bahan ajar dan model yang tepat dalam membelajarkan materi yang diajarkan. Melihat situasi ini peneliti 
berinisiatif mencoba menggunakan model pembelajaran Numbered Head Together pada pembelajaran matematika untuk lebih mengaktifkan siswa khususnya tentang operasi hitung bilangan bulat.

Numbered Head Together merupakan salah satu tipe dari model pembelajaran Cooperative Learning. Number Head Together merupakan teknik belajar mengajar Kepala Bernomor (Numbered Heads) dikembangkan oleh Spencer Kagan (1992). Tehnik ini memberikan kesempatan pada siswa untuk saling membagikan ide-ide dan mempertimbangkan jawaban yang paling tepat. Selain itu, tehnik ini juga mendorong siswa untuk meningkatkan semangat kerjasama mereka. Tehnik ini bisa digunakan untuk semua mata pelajaran dan untuk semua tingkatan usia anak didik. Model Numbered Head Together adalah bagian dari model pembelajaran kooperatif struktural, yang menekankan pada struktur-struktur khusus yang dirancang untuk mempengaruhi pola interaksi siswa. Spancer Kagan menghendaki agar para siswa bekerja saling bergantung pada kelompok-kelompok kecil secara kooperatif. Struktur tersebut dikembangkan sebagai bahan alternatif dari sruktur kelas tradisional seperti mangacungkan tangan terlebih dahulu untuk kemudian ditunjuk oleh guru untuk menjawab pertanyaan yang telah dilontarkan. Suasana seperti ini menimbulkan kegaduhan dalam kelas, karena para siswa saling berebut dalam mendapatkan kesempatan untuk menjawab pertanyaan peneliti. Oleh karena itu peneliti bersama guru bermaksud untuk mengatasi masalah yang dihadapi dengan melakukan penelitian tindakan kelas yang berjudul "Penerapan pembelajaran Kooperatif Tipe Numbered Head Together untuk Meningkatkan Hasil Belajar Siswa Mata Pelajaran Matematika Kelas IV SDN 21 Parepare"

Berdasarkan uraian di atas maka rumusan masalah dalam penelitian ini adalah:
1) Bagaimanakah proses penerapan pembelajaran kooperatif tipe Numbered Head Together pada pembelajaran matematika tentang penjumlahan bilangan bulat pada siswa kelas IV SDN 21 Parepare? Dan 2) Apakah penerapan pembelajaran kooperatif tipe Numbered Head Together dapat meningkatkan hasil belajar siswa pada mata pelajaran matematika tentang penjumlahan bilangan bulat di kelas IV SDN 21 Parepare?

\section{METODE PENELITIAN}

\section{Pendekatan dan Jenis Penelitian}

Pendekatan penelitian yang digunakan adalah pendekatan kualitatif. Penelitian tindakan kelas menunjukkan karakteristik penelitian kualitatif yang cukup kuat, terutama dalam pemaknaan apa yang terjadi di dalam proses pembelajaran, baik yang terkait dengan kondisi awal pembelajaran maupun yang terjadi setelah diterapkannya tindakan dideskripsikan dengan membentuk kata-kata dan bahasa dalam memberikan penafsiran terhadap hasilnya.

Hal ini sejalan dengan apa yang dikemukakan Nasution sesuai yang dikutip oleh Nurhidayani (2012) penelitian kualitatif memiliki ciri-ciri pengumpulan data secara deskriptif dan pengumpulan data dilakukan dalam kondisi yang alamiah atau natural setting serta peneliti mengumpulkan data berdasarkan observasi situasi yang wajar sehingga pendekatan yang digunakan adalah pendekatan kualitatif.

Jenis penelitian yang digunakan adalah penelitian tindakan kelas (PTK) yang terdiri dari tahapan perencanaan, pelaksanaan tindakan, observasi dan refleksi.

\section{Fokus Penelitian}

Fokus penelitian dalam hal ini tertuju pada fokus proses dan fokus hasil. 
a.

okus proses yaitu melihat bagaimana proses pelaksanaan pembelajaran yang dilaksanakan oleh guru dengan menggunakan model numbered head together.

b.

okus hasil yaitu melihat hasil belajar siswa setelah mengikuti pembelajaran matematika materi operasi hitung bilangan bulat dengan penggunaan model numbered head together melalui tes yang diberikan.

\section{Setting Penelitian}

Penelitian tindakan kelas (PTK) ini akan dilaksanakan di SD Negeri 21 Parepare, kelas penelitiannya yaitu kelas IV. Lokasi penelitian ini ditetapkan atas pertimbangan ditemukan hasil belajar siswa terhadap mata pelajaran matematika masih rendah dan belum pernah diterapkannya model pembelajaran numbered head together pada pembelajaran matematika khususnya materi operasi hitung bilangan bulat. Di samping itu sudah terjalin komunikasi yang baik antara kepala sekolah, guru, maupun personil-personil sekolah lainnya dengan peneliti. Pertimbangan lainnya yaitu mudah dijangkau oleh peneliti. Subjek penelitian ini adalah guru dan siswa kelas IV SD Negeri 21 Parepare pada semester genap tahun ajaran 2013/2014, dengan jumlah murid 20 orang (10 siswa laki-laki dan 10 siswa perempuan).

\section{Prosedur dan Desain Penelitian}

Pelaksanaan penelitian ini dilaksanakan dalam dua siklus, yang setiap siklusnya diadakan dalam dua kali pertemuan. Rangkaian tindakan dimulai dari perencanaan tindakan untuk mengatasi masalah tersebut, yang dilanjutkan dengan upaya pelaksanaan tindakan. Tahap selanjutnya adalah observasi. Data yang dikumpulkan kemudian di analisis. Berdasarkan hasil analisis tersebut dilakukanlah refleksi untuk mengetahui hasil dari pelaksanaan tindakan pada siklus pertama.
Hasil refleksi akan mencerminkan tingkat keberhasilan dan kegagalan yang diperoleh dalam tahap siklus pertama. Hasil refleksi ini merupakan masukan dalam merencanakan dan melaksanakan tindakan perbaikan selanjutnya.

Penelitian dilaksanakan dalam dua siklus yang dimana setiap siklusnya terdiri dari empat tahap yakni perencanaan, pelaksanaan, observasi dan refleksi. Namun sebelum memasuki tahap dari siklus pertama perlu adanya pratindakan terlebih dahulu, yaitu mengidentifikasi masalah sebelum merencanakan dan melakukan tindakan penelitian sehingga menghasilkan gagasan untuk melakukan perbaikan-perbaikan praktek guru mengajar di kelas

\section{Teknik dan Prosedur Pengumpulan Data}

Pengumpulan data dalam Penelitian Tindakan Kelas (PTK) ini berupa Observasi, tes dan dokumentasi.

a. Observasi, dilakukan untuk mengamati kesesuaian antara pelaksanaan tindakan dan perencanaan yang telah disusun selama proses pembelajaran berlangsung dengan menggunakan model pembelajaran NHT dan untuk mengetahui sejauh mana pelaksanaan tindakan dapat menghasilkan perubahan yang sesuai dengan yang dikehendaki. Teknik observasi yang digunakan berupa lembar observasi. Adapun aspek yang diamati yaitu siswa dan guru.

b. Tes, dimaksudkan untuk mengetahui sejauh mana siswa memahami materi yang diajarkan. Tes akhir setiap tindakan dimaksudkan untuk melihat hasil belajar dan aktivitas/prilaku siswa dalam pembelajaran dan untuk merefleksi hasil kegiatan sehingga dapat menentukan langkah selanjutnya dalam penelitian

c. Dokumentasi dilakukan untuk memperoleh data-data tentang hasil belajar Matematika 
kelas IV SDN 21 Parepare yang diperlukan selama proses penelitian berlangsung.

\section{Teknik Analisis Data dan Indikator Keberhasilan}

\section{a. Teknik Analisis Data}

Teknik yang digunakan dalam penelitian ini adalah teknik analisis data kualitatif. Data proses dianalisis dengan menggunakan teknik analisis data kualitatif yang dikembangkan Latri (Sulastri, 2009) yang terdiri dari tiga tahap kegiatan diantaranya yaitu:

1) Mereduksi data adalah proses kegiatan menyeleksi, memfokuskan dan menyederhanakan semua data yang telah diperoleh mulai dari awal pengumpulandata sampai penyusunan laporan penelitian.

2) Menyajikan data adalah kegiatan mengorganisasikan hasil reduksi dengan cara menyusun secara naratif sekumpulan informasi yang telah diperoleh dari hasil reduksi sehingga dapat memberikan kemungkinan penarikan kesimpulan dan pengambilan tindakan.

3) Menarik kesimpulan dan verifikasi data adalah memberikan kesimpulan terhadap hasil penafsiran dan evaluasi yang mencakup pencarian makna data serta memberikan penjelasan selanjutnya.

b.

\section{ndikator Keberhasilan}

Indikator keberhasilan hasil merupakan patokan ukuran keberhasilan hasil belajar siswa setelah mengikuti proses pembelajaran dengan menerapkan model pembelajaran numbered head together.

1)

ndikator keberhasilan proses

Saat proses pembelajaran berlangsung diamati serangkaian kegiatan yang dilaksanakan dengan menerapkan model numbered head together dalam proses pembelajaran. Penelitian dikatakan berhasil apabila guru menerapkan $70 \%$ langkah-langkah metode numbered head together dalam pembelajaran. Taraf keberhasilan 70\% sesuai tabel keberhasilan.

2)

ndikator keberhasilan hasil

Selanjutnya penetapan keberhasilan hasil belajar siswa setelah mengikuti pembelajaran dapat dilihat apabila lebih dari setengah jumlah keseluruhan siswa yang mengikuti proses belajar mengajar mencapai taraf keberhasilan minimal yakni memperoleh nilai standar KKM 70, atau memperoleh nilai optimal, atau bahkan maksimal, maka proses belajar mengajar dikatakan berhasil sehingga tidak perlu dilanjutkan ke siklus berikutnya.

\section{HASIL PENELITIAN}

Hasil penelitian yang terdiri atas aktivitas siswa dan guru dalam pembelajaran matematika dengan menerapkan model Numbered Head Together mengalami peningkatan setiap pertemuannya. Hal ini terbukti dari hasil observasi dalam pembelajaran baik itu aspek guru maupun siswa dan hasil tes formatif siswa yang dilkukan pada akhir pembelajaran. Peningkatan hasil belajar siswa terlaksana karena adanya kerjasama antara peneliti dan guru kelas yang secara kolaboratif menyusun Rencana Pelaksanaan Pembelajaran yang dilakukan secara berulang-ulang. Disetiap pelaksanaan siklus terdapat adanya kekurangan-kekurangan yang terjadi didalamnya, namun hal tersebut segera diperbaiki demi peningkatan hasil pembelajaran yang diinginkan. Pada siklus I pertemuan I, proses pembelajaran yang dilakukan oleh guru dikualisifikasikan kurang (K). Tujuan pembelajaran yang dirancang oleh peneliti yang berkolaborasi dengan guru kelas adalah siswa mampu menjumlahkan dua bilangan bulat positif dengan menggunakan 
garis bilangan dan tanpa menggunakan garis bilangan.

Pelaksanaan pembelajaran ini diawali dengan persiapan alat dan bahan yang digunakan peneliti dalam pembelajaran. Di dalam pelaksanaan pembelajaran masih terdapat berbagai kekurang-kekuangan yang dilakukan oleh guru. Namun hal tersebut segera diperbaiki oleh guru untuk peningkatan hasil belajar yang diinginkan. Berikut ini adalah beberapa kekurangan guru didalam pelaksanaan pembelajaran yang ditemukan melalui observasi: 1) pada kegiatan awal, dalam hal ini guru masih kurang dalam mengelolah kelas dengan baik, selain itu apersepsi yang dilakukan masih kurang relevan dengan materi yang akan disajikan 2) penggunaan waktu yang masih kurang efektif dalam melaksanakan tahap-tahap model pembelajaran 3) peneliti belum maksimal menanamkan konsep pembelajaran menjumlahkan dua bilangan bulat positif dengan menggunakan garis bilangan dan tanpa menggunakan garis bilangan. 4) peneliti belum maksimal dalam membimbing siswa dalam kegiatan berdiskusi secara berkelompok dan berdiskusi untuk keseluruhan kelas. Kekurangan-kekurangan dalam proses pembelajaran pada siklus I pertemuan I ini berdampak pada hasil belajar siswa. Berikut ini hasil evaluasi yang pelaksanaan pembelajaran siklus I pertemuan I.

Berdasarkan hasil tes yang diberikan menunjukan bahwa dari 20 siswa yang menjadi subyek penelitian pada siklus I pertemuan I terlihat bahwa siswa yang mendapatkan nilai 85-100 dengan kategori sangat baik sebanyak 4 siswa atau $20 \%$, siswa yang mendapatkan nilai 70-84 dengan kategori baik sebanyak 3 siswa atau $15 \%$, siswa yang mendapatkan nilai 55-69 dengan kategori cukup sebanyak 9 siswa atau $45 \%$, dan siswa yang mendapatkan nilai 46-54 dengan kategori kurang sebanyak 4 siswa atau $20 \%$, dan siswa yang mendapat nilai 0-45 dengan kategori sangat kurang sebanyak 0 siswa (lampiran 7)

Dari hasil tes yang diberikan menunjukan bahwa dari 20 siswa yang menjadi subyek penelitian pada siklus I pertemuan II terlihat bahwa siswa yang mendapatkan nilai 85-100 dengan kategori sangat baik sebanyak 4 siswa atau $20 \%$, siswa yang mendapatkan nilai 70-84 dengan kategori baik sebanyak 7 siswa atau 35\%, siswa yang mendapatkan nilai 55-69 dengan kategori cukup sebanyak 8 siswa atau $40 \%$, dan siswa yang mendapatkan nilai 46-54 dengan kategori kurang sebanyak 1 siswa atau 5\%, dan siswa yang mendapat nilai 0-45 dengan kategori sangat kurang sebanyak 0 siswa (lampiran 15). Jika kita melihat dari hasil evaluasi di atas, maka perlu diadakan perbaikan-perbaikan kesalahan yang terjadi dalam pembelajaran tersebut. Perbaikan-perbaikan tersebut dilakukan oleh peneliti pada siklu selanjutnya, yakni pada siklus II.

Keberhasilan siklus kedua mencapai kualifikasi Baik (B) karena pada kegiatan pembelajaran yang terakhir siswa mampu melaksanakan semua indikator-indikator yang direncanakan oleh peneliti. Hal ini menunjukkan bahwa siswa telah memahami betul langkah-langkah pembelajaran dengan model Numbered Head Together. Keberhasilan tindakan dari siklus pertama pertemuan I dan II ke siklus kedua pertemuan I dan II karena siswa telah memahami indikator pembelajaran dengan model Numbered Head Together. Hasil tes 20 siswa yang diperoleh pada siklus II pertemuan I ini adalah sebagai berikut: hasil tes yang diberikan menunjukan bahwa dari hasil tes yang diberikan menunjukan bahwa dari 20 siswa yang menjadi subyek penelitian pada siklus II pertemuan I terlihat bahwa siswa yang mendapatkan nilai 85-100 dengan kategori sangat baik sebanyak 7 siswa atau $35 \%$, siswa yang mendapatkan nilai $70-84$ dengan kategori baik sebanyak 7 siswa atau $35 \%$, siswa yang mendapatkan nilai 55-69 
dengan kategori cukup sebanyak 6 siswa atau $30 \%$, (lampiran 23). Sedangkan hasil tes pada siklus II pertemuan II siswa dari hasil tes yang diberikan menunjukan bahwa dari 20 siswa yang menjadi subyek penelitian pada siklus II pertemuan II terlihat bahwa siswa yang mendapatkan nilai 85-100 dengan kategori sangat baik sebanyak 8 siswa atau $40 \%$, siswa yang mendapatkan nilai 70-84 dengan kategori baik sebanyak 12 siswa atau $60 \%$, (lampiran 32)

Dari hasil evaluasi tersebut, kita dapat mengambil kesimpulan bahwa pelaksanaan tindakan pada siklus II ini mengalami peningkatan. Hal ini dikarenakan adanya perbaikan-perbaikan kesalahan yang dilakukan pada siklus I pertemuan I dan II. Berdasarkan nilai siswa pada siklus II pertemuan II dapat ditarik kesimpulan bahwa dengan menerapkan model pembelajaran numbered head together dalam pembelajaran matematika materi penjumlahan bilangan bulat dapat meningkatkan hasil belajar siswa kelas IV SDN 21 Parepare. Dengan melihat indikator keberhasilan yang ditetapkan maka penelitian ini telah berhasil, olehnya pada penelitian di siklus II ini dihentikan karena menggangap hasil pencapaian telah berhasil. Dengan begitu hipotesis yang dibangun oleh peneliti yakni jika model pembelajaran numbered head together diterapkan pada mata pelajaran matematika materi penjumlahan bilangan bulat, maka hasil belajar siswa kelas IV SDN 21 Parepare meningkat dan sudah tercapai sesuai dengan yang diinginkan.

\section{KESIMPULAN}

Berdasarkan deskripsi data dan pembahasan hasil penelitian, dapat disimpulkan bahwa hasil belajar siswa kelas IV SDN 21 Parepare mata pelajaran matematika mengalami peningkatan dari siklus ke siklus dengan menerapkan pembelajaran kooperatif tipe Numbered Head Together. Dapat dikemukakan bahwa dengan menerapkan model pembelajaran kooperatif tipe Numbered Head Together dapat meningkatkan proses aktivitas belajar matematika pada siswa kelas IV SDN 21 Parepare. Di samping itu penerapan model pembelajaran Kooperatif Tipe Numbered Head Together dapat meningkatkan hasil belajar matematika tentang penjumlahan bilangan bulat pada siswa kelas IV SDN 21 Parepare.

\section{DAFTAR PUSTAKA}

Anitah, Sri W. 2007. Strategi Pembelajaran di $S D$. Jakarta: Universitas Terbuka.

Darsono, Max. 2000. Belajar dan Pembelajaran. Semarang : CV.IKIP Semarang Press.

Depdiknas. 2006. Standar Kompetensi dan Kompetensi Dasar Tingkat SD/MI. Jakarta: BNSP.

Dimyati dan Mudjiono. Belajar dan Pembelajaran, Jakarta: Rineka Cipta.

Djmarah, dkk. 2006. Strategi Belajar Mengajar. Jakarta : Rineka Cipta

Hamalik, Oemar. 2008 . Proses Belajar Mengajar. Bandung : Bumi Aksara.

Herdian. 2009. Model Pembelajaran NHT (Numbered Head Together). Google.com (online), (diakses 20 Mei 2012).

Kusuma, Wijaya. 2009. Mengenal Penelitian Tindakan Kelas. Jakarta: PT Malta Printindo.

Mansure, Sulastri. 2009. Meningkatkan Pemahaman Konsep Peninggalan Sejarah -Hindu di Indonesia melalui Pendekatan Inkuiri Sosial di Kelas V SD Negeri 2 Lingadan Kabupaten Toli-toli Sulawesi Tengah. Makassar :Program Studi Pendidikan Guru Sekolah Dasar UNM

Mappasoro, S. dan Syamsu, A. 2006. Model-Model Pembelajaran SD. PSG Rayon 24 UNM. 
Narbuko, Cholid. dkk. 2003. Metodologi Penelitian. Jakarta: Bumi Aksara

Pasinggi, Y.S. 2010. Teori Bilangan. Parepare. Program Studi Pendidikan Sekolah Dasar

Purwanto, Ngalim. 2004. Psikologi Pendidikan. Bandung: PT Remaja Rosdakrya.

Rusman. 2010. Model-Model Pembelajaran Mengembangkan Profesionalisme Guru. Bandung : PT. Raja Grafindi Persada.

Sagala, Syaiful. 2009. Konsep dan Makna Pembelajaran. Bandung: Alfabeta.

Sardiman. 2006. Interaksi dan Motivasi Belajar Mengajar. Jakarta : Rajawali Pers

Sinring, Abdullah, dkk. 2012. Pedoman Penulisan Skiripsi Program S-1 Fakultas Ilmu Pendidikan UNM. Makassar : Fakultas Ilmu Pendidikan UNM

Sudjana,Nana. 2005. Penilaian Hasil Proses Belajar Mengajar, Bandung: PT Remaja Rosdikarya

Susilo,M Joko.2006. Gaya Belajar Menjadikan Makin Pintar. Yogyakarta : Pinus.

Trianto. 2007. Model-Model Pembelajaran Inovatif Berorientasi Konstruktivistik. Jakarta: Prestasi Pustaka Publisher.

Wardani, IGAK dkk. 2007. Penelitian Tindakan Kelas. Jakarta: Universitas Terbuka. 